\title{
Effect of induced fire on soil water repellency in the Pine (Pinus sabiniana) forest of Welihena, Matara
}

\author{
W.K. DasinkaWeerasinghe ${ }^{*}$ and R. Thivyatharsan \\ Department of Agricultural Engineering, Faculty of Agriculture, Eastern University, Sri Lanka
}

\begin{abstract}
Soil water repellency (SWR) is a reduction in the rate of wetting and retention of water in soil caused by the presence of hydrophobic coatings on soil particles. Most common methods to determine SWR are the water drop penetration time (WDPT) and molarity of ethanol droplet (MED) tests. Main aim of this study was to determine the effect of induced fire on SWR in pine forest, Welihena, Matara. Soil samples at different depth layers were collected for analysis. Induced fire experiments were carried out to determine the effect of fire intensities on SWR. According to soil textural analysis, soil was confirmed as loamy sand. Maximum WDPT (7.3s) was observed in the first layer of 0-2cm whereas minimum (1.48s) was in the deepest layer of 22$25 \mathrm{~cm}$. In fire experiment, time taken to complete the fire were 3.29minutes, 5.43minutes and 8.72 minutes for $1^{\text {st }}, 2^{\text {nd }}$ and $3^{\text {rd }}$ fire, respectively. Moisture content of soil layers of $0-2 \mathrm{~cm}, 2-4 \mathrm{~cm}$ and 4-6cm after fires varied between $23.2 \%$ and $18.1 \%$. Moisture content decreases gradually from $0-2 \mathrm{~cm}$ layer to $4-6 \mathrm{~cm}$ layer when intensity of fire increases from 3.29 minutes to 8.72minutes. The WDPT of surface soils were $43.86 \mathrm{~s}, 162.5 \mathrm{~s}$ and $415.2 \mathrm{~s}$ after $1^{\text {st }}$, $2^{\text {nd }}$ and $3^{\text {rd }}$ fires, respectively. And the WDPT of the soil layers $(0-2 \mathrm{~cm}$ to $4-6 \mathrm{~cm})$ after $1^{\text {st }}, 2^{\text {nd }}$ and $3^{\text {rd }}$ fires varied between 1.18s-5.89s, 1.14s-7.57s, 1.2s-4.76s, respectively. Based on WDPT results, soil surface becomes severely water repellent from wettable/slightly water repellent when intensity of fire increases from 0 to 8.72minutes. In addition, SWR of soil layers of 0-2cm, 2-4cm, 4-6cm become slightly water repellent from wettable when intensity of fire increases from 0 to 8.72minutes.
\end{abstract}

Keywords: Water repellency, fire, organic matter, hydrophobic coating

\section{INTRODUCTION}

Soil water repellency is a reduction in the rate of wetting and retention of water in soil caused by the presence of hydrophobic coatings on soil particles. Numerous techniques have been developed to determine the water repellency of soil. The most common method is the water drop penetration time (WDPT) test and molarity of ethanol droplet (MED) test. The creation of water repellency in soils involves both physical and chemical processes. Emergence of soil water repellency (SWR) is mainly due to soil water content and the intensity of SWR is dependent on soil organic matter, texture, etc. It is modifying physical processes such as infiltration and water movement in soils. Water repellency is produced by soil organic matter and can be found in both fire and non-fire soils (DeBano 2000).

Fire-induced water repellency in soils has been a continuous concern of watershed
Corresponding author: thivyatharsanr@yahoo.co.uk Received: 04.11.2019 https:// orcid.org/0000-0002-7898-3495

Accepted: 16.01.2020 
managers since its identification in the early 1960 (DeBano et al., 1998). The formation of water repellent soil, its chemical nature, and its effect on infiltration, runoff and erosion have all captured the attention of numerous scientists and managers worldwide.

After fire, water repellency is typically found as a discrete layer of variable thickness and spatial continuity found on the soil surface or a few centimeters below and parallel to the mineral soil surface. If found in mineral soil, water repellency is usually covered by a layer of severely burned soil or an ash layer. Creation of this water repellent layer was described as the "tin roof" effect by earlier watershed researchers. A hypothesis describing the formation of a water repellent soil layer in soils was developed during the mid and late 1960s (DeBano et al., 1998). This hypothesis evolved as a product of numerous field observations, laboratory tests and field research studies. The results of preliminary field observations suggested that water repellency might well be an important factor responsible for the accelerated erosion experienced during the first few years following wildfires (Krammes and DeBano,1965). Organic matter accumulates on the soil surface during intervals between fires. During these intervals, the upper soil horizons become water repellent due to the drying out of the mixture of partially decomposed organic matter and mineral soil. The addition of hydrophobic substances due to the leaching of decomposing plant parts on the soil surface may also contribute to the pre fire water repellency. Fungal growth also is a dynamic source of hydrophobic substances, particularly in the organic-rich upper soil horizons. Fire induced soil water repellency is often cited as a key factor controlling post-fire runoff and erosion rates (e.g., Shakesby et al., 2007; Letey, 2001).
Studies have shown that several factors affect the strength and persistence of postfire soil water repellency, including burn severity, vegetation type, soil texture, soil moisture, and time since burning (DeBano,1981; DeBano, 2000; Doerr and Thomas, 2000).

Frequent forest fire in the pine forest of some districts in intermediate and wet zones is the major problem in Sri Lanka. Matara district has extended pine forest in several places and is vulnerable to forest fire. Most of the pine forest in Matara district is in the sloppy land. Creation of soil water repellency in this forest after forest fire involves reduced infiltration, induced runoff, washed out of essential nutrients and pollution of surface water bodies. In this context, this study was mainly aimed to determine the effect of induced fire on soil water repellency in the pine forest of Welihena, Matara. The hypothesis tested: was there a relationship between the intensity of fire and soil water repellency of soil layers. This study will be very useful for soil managers to overcome the problem of soil water repellency in a short period of time after getting forest fire.

\section{Objectives}

1. To determine the occurrence of soil water repellency in the pine forest soil of Welihena, Matara

2. To determine the effect of induced fire on soil water repellency.

\section{MATERIALS AND METHODS}

\section{Field assessment of soil water repellency}

Area of $100 \mathrm{~m} \times 100 \mathrm{~m}$ was selected and divided into $10 \mathrm{~m} \times 10 \mathrm{~m}$ grids. The litters found on the soil surface was removed and WDPT test (Dekker and Ritsema, 1994) was performed at the middle of the grids. The 
WDPT test at $5 \mathrm{~cm}$ intervals from the surface down to $25 \mathrm{~cm}$ for core samples (using a small core sampler of $1.5 \mathrm{~cm}$ wide and $25 \mathrm{~cm}$ long)taken at 25 places within the same $100 \mathrm{~m} \times 100 \mathrm{~m}$ area was also performed.

For WDPT test, three drops of distilled water were placed on the smoothed surface of a soil sample, using a standard medicine dropper, and the time that elapses before the drops are absorbed was determined. The threshold of 5s (Bisdom et al., 1993) was used to differentiate between wettable and water repellent soils. Dekker and Jungerius (1990) distinguished the following seven classes of repellency on the basis of the time needed for the water drops to penetrate into the soil: class 0, wettable, non-water repellent (infiltration within $5 \mathrm{~s}$ ); class 1 , slightly water repellent (5-60 s); class 2, strongly water repellent (60-600 s); class 3, severely water repellent (600-3600 s); and extremely water repellent $(>1 \mathrm{~h})$, further subdivided into class 4 (1-3 h); class 5 (3-6 h); and class 6 (>6 h).

\section{Soil sampling}

Three sampling points were located in the distance of $50 \mathrm{~m}$ between points in the field. Samples at different depth layers of $0-2 \mathrm{~cm}$, $2-4 \mathrm{~cm}, 4-6 \mathrm{~cm}, 6-8 \mathrm{~cm}, 8-10 \mathrm{~cm}, 10-13 \mathrm{~cm}$, $13-16 \mathrm{~cm}, \quad 16-19 \mathrm{~cm}, \quad 19-22 \mathrm{~cm}$ and $22-$ $25 \mathrm{cmcollected}$, packed and transferred to laboratory.

\section{Laboratory assessment of soil water repellency}

The soil physical and chemical characters such as $\mathrm{pH}$, electrical conductivity, soil texture, moisture content (volumetric water content), bulk density and soil organic matter were measured using standard procedures. The table 1 shows the physical and chemical characters of soil layers.

Immediately after transferring to laboratory, the WDPT test was performed at field moisture content for soil layers mentioned above in a soil profile down to $25 \mathrm{~cm}$. Sub samples of each soil layers were air-dried for about 2/3 weeks, grinded and sieved through a $2 \mathrm{~mm}$ mesh. The WDPT test was performed at room temperature for air-dried samples.

Table 1: Physical and chemical characters of soil layers (Mean and SE)

\begin{tabular}{|c|c|c|c|c|c|c|c|c|}
\hline \multirow{2}{*}{$\begin{array}{c}\text { Depth } \\
\text { (cm) }\end{array}$} & \multirow{2}{*}{$\begin{array}{c}\text { Field } \\
\operatorname{MC}(\%)\end{array}$} & \multirow{2}{*}{$\begin{array}{c}\text { BD } \\
(\mathrm{g} / \mathrm{cm} 3)\end{array}$} & \multirow[t]{2}{*}{ pH } & \multirow[t]{2}{*}{$\mathrm{EC}(\mathrm{mS} / \mathrm{m})$} & \multicolumn{3}{|c|}{ Soil texture } & \multirow[t]{2}{*}{ OM (\%) } \\
\hline & & & & & Sand\% & Clay\% & Silt \% & \\
\hline $0-2$ & 14.68 & $0.90 \pm 0.03$ & $6.5 \pm 0.10$ & $0.12 \pm 0.01$ & 94.8 & 5.0 & 0.1 & $3.30 \pm 0.84$ \\
\hline $2-4$ & 31.56 & $1.16 \pm 0.13$ & $6.2 \pm 0.10$ & $0.11 \pm 0.02$ & 94.8 & 4.9 & 0.2 & $2.00 \pm 0.56$ \\
\hline $4-6$ & 23.12 & $1.01 \pm 0.05$ & $6.2 \pm 0.13$ & $0.10 \pm 0.02$ & 94.8 & 4.9 & 0.2 & $0.22 \pm 0.18$ \\
\hline $6-8$ & 28.12 & $1.11 \pm 0.12$ & $6.3 \pm 0.17$ & $0.09 \pm 0.01$ & 94.8 & 5.0 & 0.1 & $<0.01$ \\
\hline $8-10$ & 29.65 & $1.18 \pm 0.18$ & $6.6 \pm 0.10$ & $0.08 \pm 0.02$ & 94.8 & 5.1 & 0.1 & $<0.01$ \\
\hline $10-13$ & 30.57 & $1.16 \pm 0.20$ & 6.2 & $0.08 \pm 0.01$ & 94.8 & 5.1 & 0.1 & $<0.01$ \\
\hline $13-16$ & 28.75 & $1.16 \pm 0.13$ & $6.4 \pm 0.03$ & $0.07 \pm 0.01$ & 92.5 & 6.6 & 0.9 & $<0.01$ \\
\hline $16-19$ & 29.35 & $1.13 \pm 0.17$ & $6.2 \pm 0.07$ & 0.07 & 92.4 & 6.8 & 0.8 & $<0.01$ \\
\hline $19-22$ & 32.34 & $1.25 \pm 0.18$ & $6.2 \pm 0.07$ & 0.07 & 92.2 & 6.9 & 0.9 & $<0.01$ \\
\hline $22-25$ & 22.94 & $1.02 \pm 0.05$ & $6.1 \pm 0.07$ & 0.08 & 92.1 & 7.2 & 0.7 & $<0.01$ \\
\hline
\end{tabular}


Determine the effect of fire intensity on soil water repellency

Experimental soil plots $(10 \mathrm{~cm}$ x $10 \mathrm{~cm})$ were prepared in an Agricultural Engineering workshop, Department of Agricultural Engineering, Faculty of Agriculture as same as the field. Different amounts such as 50, $100,200 \mathrm{~g}$ of pine litters were added on the surface of the experimental plots with three replicates and burnt to determine the effect of fire intensities on SWR. The time required to complete the burning was also recorded. The WDPT test was performed in the layers of $0-2 \mathrm{~cm}, 2-4 \mathrm{~cm}$ and $4-6 \mathrm{~cm}$ in a soil profile.

\section{Data Analysis}

Data analysis was performed using MS Excel, 2010 and Mini Tab, 2014.

\section{RESULTS AND DISCUSSION}

\section{Naturally occurring surface soil water repellency}

The WDPT test results indicate that $72 \%$ of the surface soil within 1 ha exhibited slight water repellency while $28 \%$ of surface soil has no water repellency (Fig 1). It was mainly observed in the surface soils. In order to confirm whether the soils under the pine forest exhibits WR, the same WDPT test was conducted in the grass land adjacent to the study area. Though the soil texture (loamy sand) of these two lands is same, the grass land soils showed no water repellency. Thus, it is confirmed that the soils under the pine trees exhibit WR.

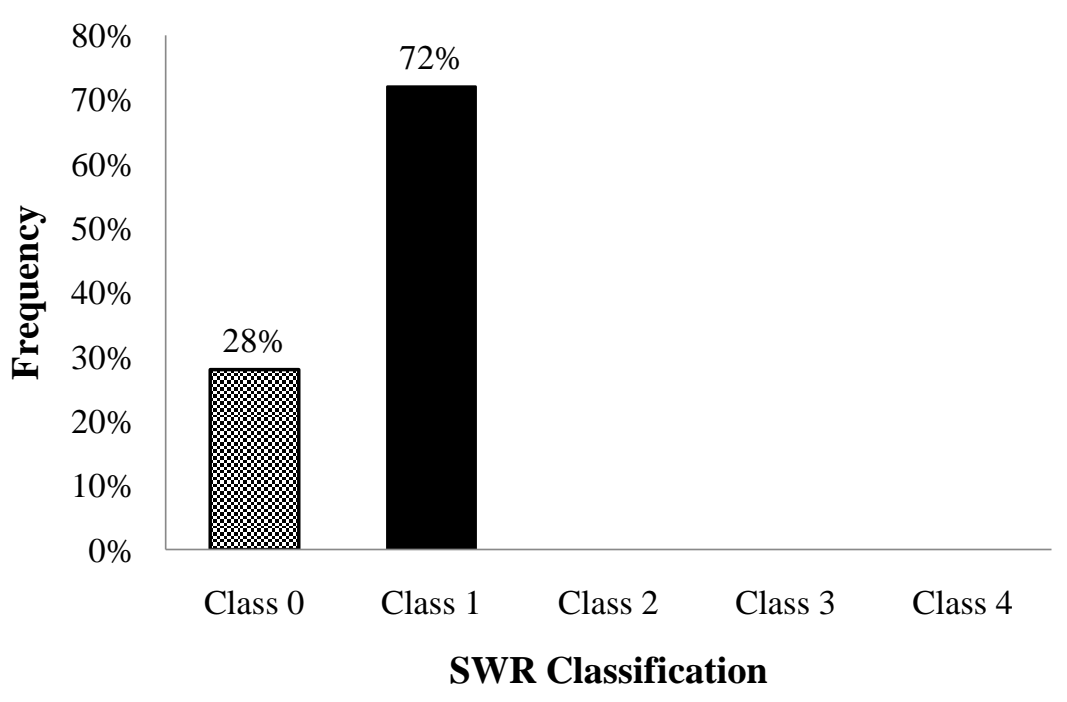

Figure 1: Naturally occurring surface soil water repellency in pine plantation

The exact chemical composition of substances responsible for the generation of soil water repellency is difficult to identify, but they all are generally organic compounds which accumulate on, and between soil particles. Organic compounds with hydrophobic properties are naturally rich in the biosphere and can be released gradually into the soil. Examples for factors that affect to soil water repellency are waxy substances from leaves (Passialis and Voulgaridis, 1999), root exudates (Dekker 
and Ritsema, 1996), fungi (Fidanza, et al., 2007), microbes (Hallett and Young, 1999) and decomposing organic matter (McGhie and Posner, 1980). In forests, organic matter accumulates in the litter layers. Therefore, in the upper soil layers, water repellency is developed due to the intermixing of partly decomposed organic substances and mineral soil and also due to the leachate from brush and decomposing plant particles which deposited in the upper soil profile. In this part of the soil, water repellency can also be produced by fungal growth (DeBano, 1981).Soil of pine plantation has higher amount of waxy organic substances. Also, there are waxy substances which extracted from the stem and the roots of the pine plant that can also contribute to develop water repellency. Most important factor which affect to increasing severity of water repellency of plantation site is formation of soil aggregates that resulted by chemical bonding of soil, litters and waxy substances together.

\section{Soil water repellency changes with soil depth}

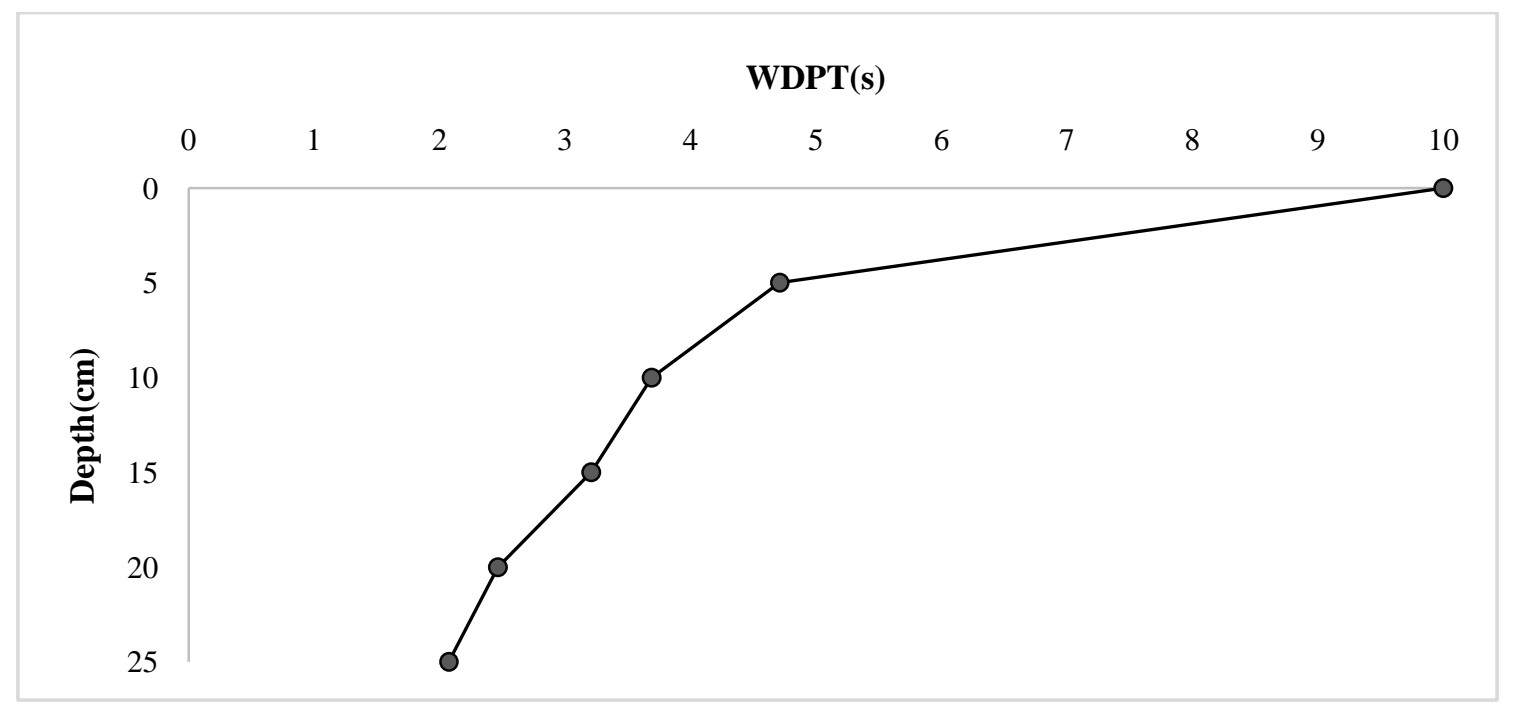

Figure 2: Changes of SWR with soil depth

The water repellency test was done by taking soil core samples $(\mathrm{n}=150)$ using core sampler of $1.5 \mathrm{~cm}$ wide and $25 \mathrm{~cm}$ long. In pine plantation, surface soil and top layers exhibited water repellency and reduced suddenly to the depth of $5 \mathrm{~cm}$ and then, water repellency was decreased gradually up to the depth of $25 \mathrm{~cm}$ (Fig 2). This is mainly because of the reduction of organic matter (3.05\% to $0.03 \%$ ) from the surface to $5 \mathrm{~cm}$ depth. And, no soil water repellency was observed from $5 \mathrm{~cm}$ to $25 \mathrm{~cm}$ depth as these soils have no organic matter. 


\section{Relationship between soil properties and SWR}

Table 1: Matrix of correlation coefficients $(R)$ for soil variables of pine plantation

\begin{tabular}{llllll}
\hline & OM & BD & pH & EC & WDPT(s) \\
\hline OM & 1 & & & & \\
BD & -0.420 & 1 & & & \\
pH & 0.644 & 0.163 & 1 & & \\
EC & 0.874 & $-0.424^{*}$ & 0.244 & 1 & \\
WDPT(s) & 0.577 & -0.308 & 0.070 & $0.550^{*}$ & 1 \\
\hline
\end{tabular}

$*, * *, * * *$ Statistical significance at the $0.05,0.01$ and 0.001 level

The values describe the correlation of selected soil properties from the top layer of $0-2 \mathrm{~cm}$ to the deepest layer of 22 $25 \mathrm{~cm}$

Statistically significant correlation was found between SWR and raw organic matter $(\mathrm{R}=0.577)$. Presence of organic matter is an inherent property of many forest soils. In forest soil, various organic acids are released either from living biomass or decomposing plant and microbial residues. This nonhumified fraction which is present in the soil in the form of particulate matter or organic coating is composed of non-polar or amphilic organic substances such as waxes, fatty acids, their esters and salts, phytanes, phytols and sterols. If these compounds are present in soil in higher amounts, they impede the water which contacts the soil from entering its pore system.

It was also found the significant positive relationship between EC and persistence of SWR $(\mathrm{R}=0.550, \mathrm{P}<0.05$. Further, there was a negative correlation ( $R=-0.308)$ between bulk density and persistence of SWR in pine plantation soil.

\section{Fire induced water repellency in pine soil (In surface soil)}

The WDPT of surface soils after burning were $43.86 \mathrm{~s}, 162.5 \mathrm{~s}$ and $415.2 \mathrm{~s}$ for $1^{\mathrm{st}}, 2^{\text {nd }}$ and $3^{\text {rd }}$ fires, respectively. The severity of soil water repellency increases when the fire intensity increases. It means the soil changes from slight to severe water repellent as it burns intensely. In burned soils, the severity of water repellency is depended on soil texture, organic matter, fire intensity and soil-water content (DeBano et al., 1976).In this soil, water repellency may be induced by drying of organic matter mainly in the surface soils, which have difficulties to rewet after drying (Van'tWoudt, 1969) or heating of the coated particles or the intermixed soil may markedly increase soil water repellency (Cory and Morris, 1969), (DeBanoand Krammes, 1966). If the soil is a mixture of organic matter and mineral soil, heating causes the organic matter to coat the adjacent mineral soil particles (DeBano and Krammes, 1966). 


\section{In soil depth layers}

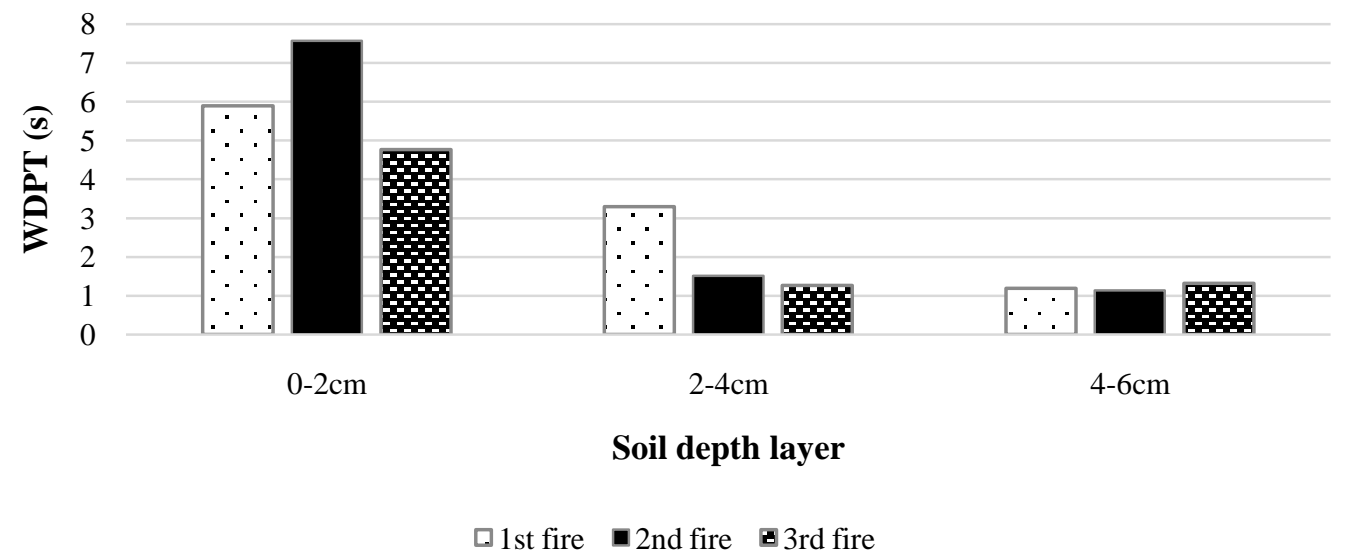

Figure 3: WDPT after fire experiment

Figure 3 demonstrates the relationship between soil water repellency and fire intensity. The $2^{\text {nd }}$ fire (100 $\mathrm{g}$ pine debris) shows highest WDPT value (7.57 s) in soil surface whereas lowest WDPT value is observed in $3^{\text {rd }}$ fire $(200 \mathrm{~g}$ pine debris). A little difference in WDPT values is observed in the soil layer of $4-6 \mathrm{~cm}$.It explains that the fire induces the soil water repellency mainly in the top layers than in the deeper layers. It may be due to the higher organic matter content in the top layers. It was also observed in the experiment that the soil water repellency increased when the intensity of fire increases, Thereafter, the reduction of soil water repellency was observed while increasing the fire intensity continuously. This is because the severe fire intensity on soil burns the soil to ash. Therefore, repellency was highest in $1^{\text {st }}$ fire and then reduced in subsequent burning.

\section{Relationship between moisture content and soil water repellency after induced fire}

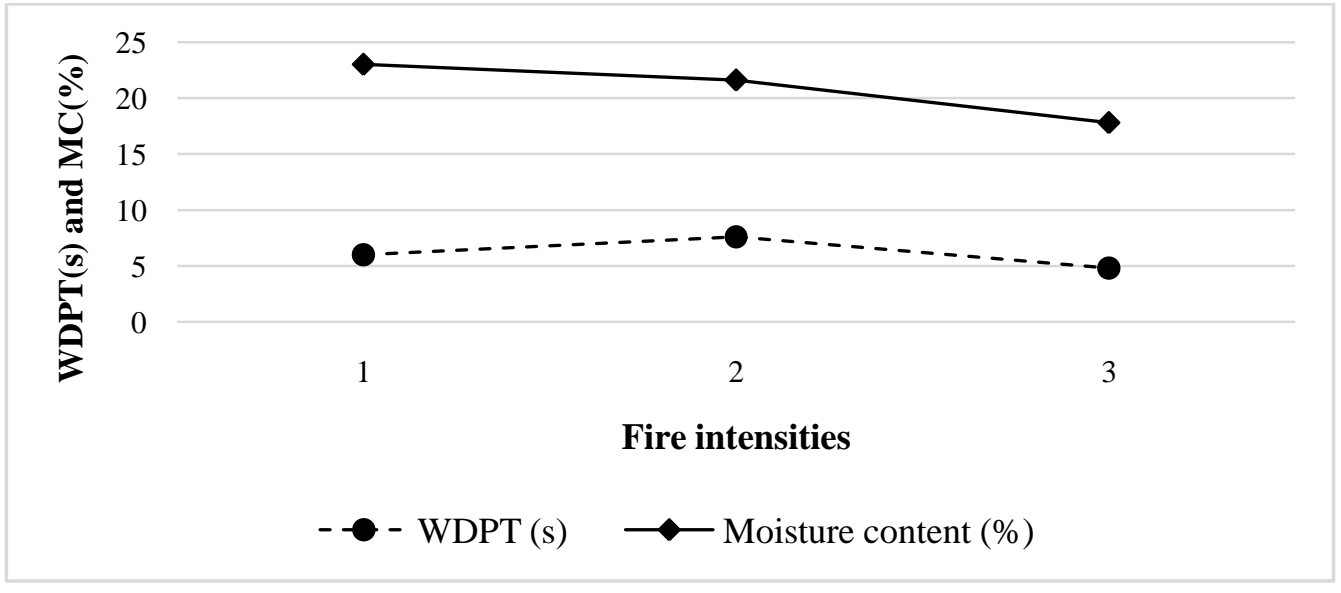

Figure 4: Relationship between moisture content and WDPT after fire 
Figure 4 shows the relationship between moisture content and WDPT after fire. The moisture content shows considerable variation for different fire intensities $\left(1^{\text {st }}, 2^{\text {nd }}\right.$ and $3^{\text {rd }}$ fires). The moisture content decreases gradually from $23.2 \%$ to $18.1 \%$ as the fire intensities increases. The WDPT was almost lower than the moisture content. Soil water repellency increases when the moisture content decreases from $1^{\text {st }}$ fire to $2^{\text {nd }}$ fire. As shown in figure 4, with the further reduction of soil moisture, the soil water repellency reduces because at the higher temperatures hydrophobicity of the soils again turn into the hydrophilic condition.

\section{CONCLUSION}

In natural pine forest soil, it is difficult to identify the substances responsible for the generation of soil water repellency, but generally organic compounds which accumulate on, and between soil particles. The severity of soil water repellency is mainly determined by the moisture content of soil. The induced fire changes the moisture content of soil layers which in turn determine the severity of soil water repellency. According to WDPT results obtained, the soil surface becomes severely water repellent from wettable/slightly water repellent when intensity of fire increases. And the soil water repellency of soil layers also become slightly water repellent from wettable when intensity of fire increases. Therefore, it can be concluded that the intensity of fire is a main cause of determining the severity of water repellency in the soils of pine forest. Assessing the soil water repellency in pine forest immediately after fire will help the soil managers to manage the soil properly to rectify the problem of water repellency of soil layers in order to conserve the water and nutrients, and minimize soil erosion.

\section{REFERENCES}

Bisdom, E. B. A., Dekker, L. W., \& Schoute, J. T. (1993). Water repellency of sieve fractions from sandy soils and relationships with organic material and soil structure. In Soil Structure/Soil Biota Interrelationships (pp. 105-118). Elsevier.

Cory, J. R., \& Morris, R. J. (1969). Factors restricting infiltration rates on decomposed granitic soils. In Water Repellent Soils. Proceedings of the Symposium on Water Repellent Soils. Univ. Calif., Riverside, $\mathrm{Pp}$ 149-161.

DeBano, L. F. (1981). Water repellent soils: a state-of-the-art. Gen. Tech. Rep. PSW-46. Berkeley, Calif.: US Department of Agriculture, Forest Service, Pacific Southwest Forest and Range Exp. Stn. 21 $p, 46$.

DeBano, L. F. (2000). The role of fire and soil heating on water repellency in wildland environments: a review. Journal of hydrology, 231, 195-206.

DeBano, L. F., \& Krammes, J. S. (1966). Water repellent soils and their relation to wildfire temperatures. Hydrological Sciences Journal, 11(2), 14-19.

DeBano, L. F., Neary, D. G., \& Folliott, P. F. (1998). Fire effects on ecosystems. John Wiley \& Sons.

DeBano, L. F., Savage, S. M., \& Hamilton, D. A. (1976). The Transfer of Heat and Hydrophobic Substances During Burning 1. Soil Science Society of America Journal, 40(5), 779-782.

Dekker, L. W., \& Jungerius, P. D. (1990). Water repellency in the dunes with special 
reference to the Netherlands. Catena, Supplement, (18), 173-183.

Dekker, L. W., \& Ritsema, C. J. (1994). How water moves in a water repellent sandy soil: Potential and actual water repellency. Water Resources Research, 30(9), 2507-2517.

Dekker, L. W., \& Ritsema, C. J. (1996). Uneven moisture patterns in water repellent soils. Geoderma, 70(2-4), 87-99.

Doerr, S. H., \& Thomas, A. D. (2000). The role of soil moisture in controlling water repellency: new evidence from forest soils in Portugal. Journal of Hydrology, 231, 134147.

Fidanza, M. A., Cisar, J. L., Kostka, S. J., Gregos, J. S., Schlossberg, M. J., \& Franklin, M. (2007). Preliminary investigation of soil chemical and physical properties associated with Type- I fairy ring symptoms in turf grass. Hydrological Processes: An International Journal, 21(17), 2285-2290.

Hallett, P. D., \& Young, I. M. (1999). Changes to water repellence of soil aggregates caused by substrate- induced microbial activity. European Journal of Soil Science, 50(1), 35-40.

Krammes, J. S., \& DeBano, L. F. (1965). Soil wettability: a neglected factor in watershed management. Water Resources Research, 1(2), 283-286.

Letey, J. (2001). Causes and consequences of fire induced soil water repellency. Hydrological Processes, 15(15), 2867-2875.

McGhie, D. A., \& Posner, A. M. (1980). Water repellence of a heavy textured Western Australian surface soil. Soil Research, 18(3), 309-323.

Passialis, C. N., \& Voulgaridis, E. V. (1999). Water repellent efficiency of organic solvent extractives from Aleppo pine leaves and bark applied to wood. Holzforschung, 53(2), 151-155.

Shakesby, R. A., Wallbrink, P. J., Doerr, S. H., English, P. M., Chafer, C. J., Humphreys, G. S., \& Tomkins, K. M. (2007). Distinctiveness of wildfire effects on soil erosion in south-east Australian eucalypt forests assessed in a global context. Forest Ecology and Management, 238(1-3), 347-364.

Van'tWoudt, B. D. (1969). Resistance to wetting under tropical and subtropical conditions. In Water Repellent Soils. Proceedings of the Symposium on Water Repellent Soils. Univ. Calif., Riverside (p. 7). 